\title{
O Mito Inesiano na Literatura Portuguesa: uma análise na produção poética de Eugênio de Castro e Miguel Torga
}

Rondinele Aparecido Ribeiro ${ }^{1}$

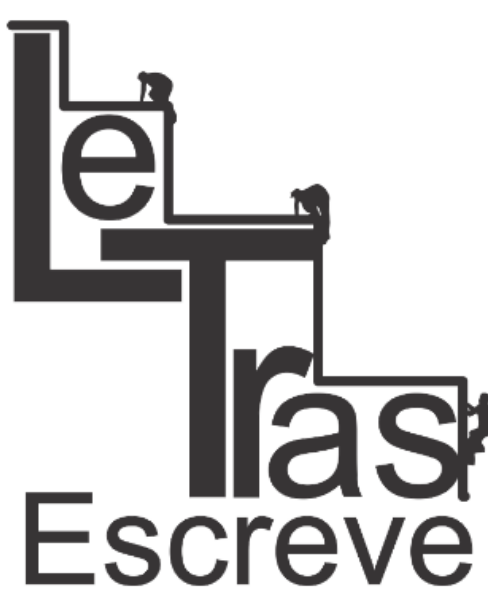

(ISSN 2238-8060)

Resumo: O mito inesiano perpassa gerações e se perpetua no tempo. A história de um amor proibido com consequências trágicas foi registrada nas mais variadas estéticas literárias. Do Humanismo, passando pelo Classicismo e pelo Modernismo, algum autor buscou retomar a história trágica entre Inês de Castro e D. Pedro. Assim, o presente artigo objetiva tecer considerações a respeito dessa manifestação amorosa bem como de sua importância mítica para Portugal, já que Garmes e Siqueira (2009) asseveram que o mito inesiano serviu para a construção identitária portuguesa. Dessa forma, após contextualizarmos a temática, faremos a análise estrutural dos poemas Inês de Castro, de Miguel Torga e Inês e Constança, de Eugênio de Castro. Sabemos que os dois são pertencentes a épocas bem distintas, mas que têm em comum a temática mítica. Situaremos a questão da construção mítica de Inês de Castro, utilizando como suporte teórico o texto Mito e realidade, de Mircea Eliade.

Palavras-chave: Mito. Identidade. Literatura Portuguesa.

Abstract: The inesiano myth permeates generations and is perpetuated in time. The story of a forbidden love with tragic consequences was recorded in the most varied literary aesthetic. Humanism, through Classicism and Modernism by, any author sought to resume the tragic story of Ines de Castro and Pedro. Thus, this article aims to make considerations about this loving expression as well as their mythic importance for Portugal, since Garmes and Siqueira (2009) assert that the inesiano myth served to the Portuguese identity construction. Thus, after contextualize the theme, we will do the structural analysis of Inês de Castro poems by Miguel Torga and Ines and Constance de Castro Eugenio. We know that the two are owned by very different times, but they have in common the mythical theme. We will place the question of the mythical building Inês de Castro, using as theoretical support the text Myth and reality of Mircea Eliade.

Keywords: Myth. Identity. Portuguese literature.

\section{Introdução}

Em seu ensaio intitulado Mito e a realidade, Mircea Eliade assevera que o mito é compreendido como algo vivo, que determina

\footnotetext{
1 Docente da Faculdade do Norte Pioneiro - FANORPI/UNIESP. Tem Especialização em Cultura, Literatura Brasileira e Língua Portuguesa. Possui licenciatura em Letras/Literatura pela UENP (2011). Membro do GP Cultura Popular e Tradição Oral: Vertentes (UNESPASSIS). Contato: rondinele-ribeiro@bol.com.br
}

https://periodicos.unifap.br/index.php/letras

Macapá, v. 6, n. I, Io semestre, 2016. 


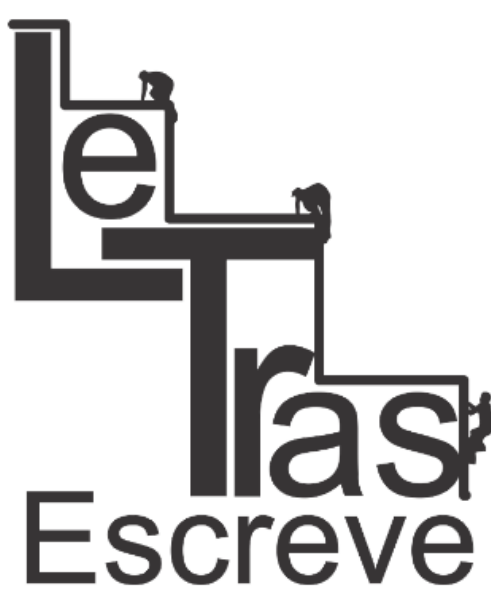

(ISSN 2238-8060) e explica as atitudes do povo que o entendia dessa maneira. Sendo assim, o estudo do mito é essencial, uma vez que por meio desse olhar, captamos o sentido de "estranhas" formas de conduta para uma maior compreensão dos excessos, a cultura e espiritualidade dessa sociedade.

O autor define o mito como sendo uma realidade cultural extremamente complexa, que pode ser abordada e interpretada através de perspectivas múltiplas e complementares. Para ele, é extremamente difícil encontrar uma definição que fosse aceita por todos os eruditos e, ao mesmo tempo, acessível a não-especialistas. Dessa maneira, a definição menos imperfeita seria a de que o mito centra sua finalidade em torno de uma historia sagrada. Ele relata um acontecimento ocorrido no tempo primordial, o tempo fabuloso do "princípio". O mito fala apenas do que realmente ocorreu, do que se manifestou plenamente. Em suma, os mitos descrevem as diversas, e, algumas vezes, dramáticas irrupções do sagrado (ou do "sobrenatural") no mundo. Para o autor, o mito pode ser alçado ao posto de história verdadeira, haja vista que seu escopo é tratar acerca de realidades, o que o tornaria uma espécie de matriz para as atividades significativas humanas.

Sendo o mito uma história sagrada ocorrida no tempo primordial, ele se torna essencial para esclarecer as atitudes e a cultura dos antigos, que o viam como verdade inquestionável e absoluta, até mesmo por dizer ao povo o motivo de sua existência, pois a ciência não explica isso. Sabemos que para o homem arcaico, o mito se reveste de um caráter extremamente importante, pois, como já foi afirmado, ensina histórias primordiais, que entram na constituição existencial do homem.

Em seus postulados, Mircea Elíade apresenta também uma diferenciação entre o modo como o homem arcaico e o homem moderno compreendem o mito. $\mathrm{O}$ autor comenta que para $\mathrm{o}$ primeiro, o mito é uma forma de ensinamento das histórias primordiais que adentram em sua constituição existencial. Já quanto

https://periodicos.unifap.br/index.php/letras Macapá, v. 6, n. I, Io semestre, 2016. 


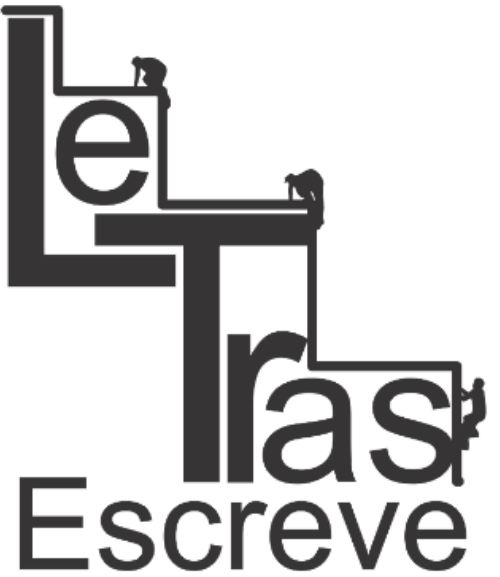

(ISSN 2238-8060) ao segundo, explica Eliade, que sua constituição se dá por meio da História.

Tecendo considerações mais amplas acerca da afirmação acima, pode-se dizer que, para o homem arcaico, o mito explica o motivo de sua existência, além de ser a própria crença em que eles se tornam heróis. Dessa forma, trata-se de um meio que os arcaicos encontram de reproduzir os grandes feitos de seus heróis ao mesmo tempo que os aproxima deles e de sua história. Dessa forma, para os arcaicos, conhecer os mitos é aprender o segredo da origem das coisas.

Por sua vez, para o homem atual, tudo deve ser concreto, comprovado, ou seja, o homem atual é um questionador, racional. Isso justamente explica a diferença com que o homem moderno e o homem arcaico o veem, pois para o primeiro é uma história fictícia, já para o segundo uma história sagrada verdadeira e viva. Outra grande diferença reside no fato da irreversibilidade dos acontecimentos, uma vez que para os arcaicos há o raciocínio de que sua existência está atrelada ao fato da ocorrência de eventos anteriores a sua existência. Eles sentem a necessidade de rememorar sua história mítica, reatualizando periodicamente grande parte dela. Já para o homem moderno, a irreversibilidade dos acontecimentos é encarada como nota característica da história, não constituindo uma evidência para o primeiro.

Modernamente, o mito é estudado em duas acepções. A primeira, o encara como ficção, ilusão; A segunda, como sagrado. Vale lembrar que na Grécia, era designado como tudo aquilo que não podia existir. Constantemente, essa primeira etapa do conhecimento era uma necessidade humana, à medida que narravam efetivamente não apenas a origem do mundo, dos animais, das plantas e do homem, mas também de todos os acontecimentos primordiais em consequência dos quais o homem se converteu no que é hoje: um ser mortal, sexuado, organizado em

https://periodicos.unifap.br/index.php/letras Macapá, v. 6, n. I, Io semestre, 2016. 
sociedade, obrigado a trabalhar para viver, e trabalhando de acordo com determinadas regras.

Sabe-se que tais mitos foram se transformando $e$ enriquecendo no curso dos séculos, sob a influência de outras culturas superiores ou graças ao gênio criador de alguns indivíduos excepcionalmente bem dotados. Dessa forma, pode-se afirmar que todos somos carregados de uma história que explica o porquê somos como somos hoje. O mito, então, é o fio condutor da nossa história e antepassados, por isso sempre se recorre a ele para possuir respostas. Motivo esse também que nos faz pensar que o mito é uma realidade viva em nós.

Após tecermos considerações acerca do mito, faremos uma contextualização acerca da constituição mítica em Inês de Castro.

\section{Contextualização sobre o caso amoroso entre Inês e D. Pedro}

Inês de Castro nasceu entre 1320 e 1325 na Galícia. Era filha de Pedro Fernandes de Castro, que era um funcionário do trono espanhol. Mesmo sendo bastarda, Inês teve sua infância junto da família nobre e rica. Mais tarde, tornou-se dama de companhia de D. Constança, que era prima de Inês. Assim, a trajetória de Inês de Castro, como aduz Garmes e Siqueira (2009) pode ser resumida da seguinte forma: sua origem não é portuguesa, mas sim da Galícia, podendo ser denominada de controversa, haja vista ser filha bastarda da aristocracia; teve sua morte bastante cedo aos 30 anos e foi declarada rainha de Portugal depois de morta.

Recuperar a história de amor proibido vivida por Inês e D. Pedro é fundamental para entender o episódio trágico na monarquia portuguesa, que se transformou num verdadeiro mito acerca da nação. Sabe-se que o regente $D$. Pedro, conheceu Inês de Castro quando contraiu matrimônio com Dona Constança por vontade de seu severo pai, D. Afonso IV. Inês de Castro era uma dama de companhia Dona Constança. Como já afirmado, era filha bastarda 


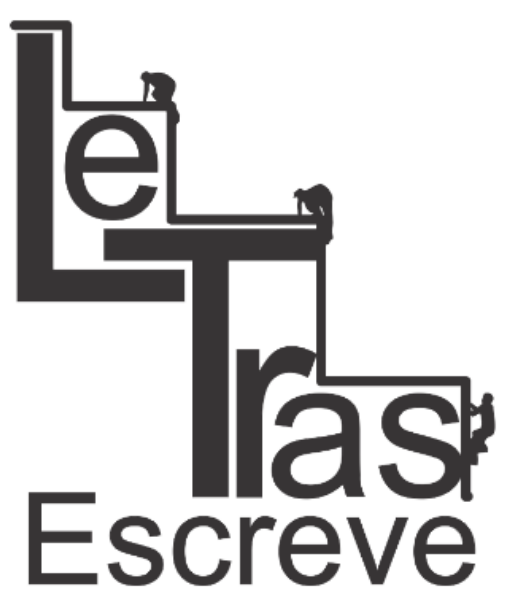

(ISSN 2238-8060)

de um nobre fidalgo espanhol e de uma senhora portuguesa com quem o senhor tinha um caso amoroso.

Surge entre Inês e o príncipe um grande relacionamento de amantes. "Seu relacionamento amoroso era tão intenso e aberto que provocou a desaprovação da corte" (GARMES; SIQUEIRA, 2009, p.14-15). Como relata Garmes e Siqueira (2009), Dona Constança sabia dessa relação amorosa entre D. Pedro e Inês e como forma de impedir a continuidade de tal relação, convidou a prima para ser madrinha do primogênito do casal, uma vez que pelas leis canônicas da época, a relação entre madrinha e pais era vista como incesto. Tal atitude de D. Constança não logrou êxito e o rei Afonso IV acabou expulsando Inês da corte e a exilou em um castelo que ficava nas proximidades com a Espanha.

Mesmo estando separados, os amantes continuavam a se comunicar:

\begin{abstract}
Mesmo separados, Pedro e Inês continuaram se comunicando e mantiveram forte o sentimento que os ligava. Foi quando uma fatalidade permitiu o retorno de Inês e a continuação de seu caso amoroso com o príncipe: ao ter seu terceiro filho (Fernando, que se tornaria o rei português após a morte de D. Pedro), Constança morreu. Viúvo, o herdeiro do trono de Portugal sentiu-se livre para manter Inês a seu lado, até com a possibilidade de torná-la sua esposa (GARMES; SIQUEIRA, 2009, p.15).
\end{abstract}

Com a morte de D. Constança. D. Pedro tem, então, caminho livre para continuar um relacionamento com Inês de Castro, por esse motivo recusa casar-se com outras senhoras, alegando que ainda estava em luto e que não havia esquecido a "amada" Constança.

$\mathrm{Na}$ realidade, essa relação culmina até em um casamento secreto. Pedro havia levado a amada para residir no palacete em Coimbra. O Paço Santo Clara era uma belíssima construção implementada por D. Isabel, que era avó de Pedro. "Essa decisão de D. Pedro foi considerada uma provocação. O escândalo que a situação causava era crescente, com a desaprovação tanto da

https://periodicos.unifap.br/index.php/letras Macapá, v. 6, n. I, Io semestre, 2016. 
nobreza quanto do povo em geral” (GAMES; SIQUEIRA, 2009, p.15).

$\mathrm{Na}$ realidade, a atitude de desaprovação da nobreza tinha mais um fundo político que moral, uma vez que Inês de Castro tinha origem nobre de uma família de grande poder e prestígio na Espanha, os Castros. Desconfiava-se que os irmãos de Inês já bastante próximos de $\mathrm{D}$. Pedro haviam estimulado a união movido pelo viés político, já que o pai de Inês era da linhagem real espanhola e, em virtude disso, Pedro poderia, mais tarde, exigir o trono português, unificando assim os dois reinos.

Conforme explica Garmes e Siqueira:

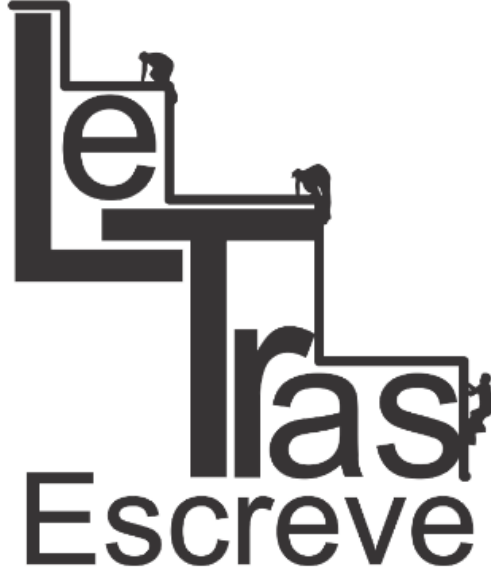

(ISSN 2238-8060)

A ideia repugnava o rei Afonso e a maioria da nobreza, que viam em semelhantes conluius a possibilidade de Portugal submergir dentro da Espanha, perdendo sua autonomia e a identidade. Os espanhóis construíam na época um poderoso reino, de grande força militar e sentimento de unidade. Não seria Portugal a anexar a Espanha, e sim o contrário (GARMES, SIQUEIRA, 2009, p.15)

Diante das circunstâncias, D. Afonso decide tirar brutalmente a vida de Inês de Castro numa tentativa de recuperar a Pedro quando estava preso por amor. Aproveitando-se que D. Pedro havia se ausentado para praticar caça, atividade de que gostava bastante, Inês é assassinada sob a acusação de traição. A jovem contava com 30 anos de idade e foi degolada em 07 de janeiro de 1355.

Quando Pedro descobriu o que havia acontecido, acabou rompendo relações com o pai, tendo início a uma guerra civil, que durou cerca de dois anos, tendo sido resolvida por intermédio de D. Beatriz de castelã, mãe de Pedro. Nesse embate, Pedro saí fortalecido e passa ser o governante de Portugal. Nas circunstâncias de falecimento do pai, D. Pedro é coroado rei pune severamente os algozes de Inês: Pero Coelho, Álvaro Gonçalves, Diogo Lopes Pacheco. Os três acabaram fugindo para a Espanha, mas foram entregues pelo rei Espanhol, que negociou com Pedro uma troca de 


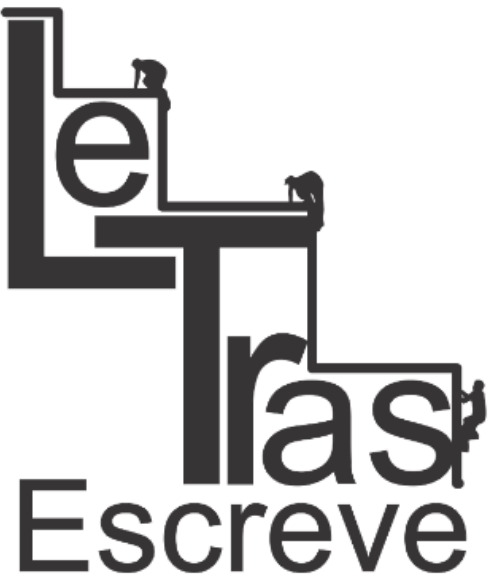

(ISSN 2238-8060)

desafetos. Todavia, a prisão de Diogo Lopes Pacheco não foi possível, uma vez que ele acabou fugindo para a França.

A punição dos dois algozes presos consistiu numa execução. Primeiramente, os dois foram torturados até delatarem outros participante na execução. Os dois tiveram os corações arrancados ainda vivos, já que o rei tinha a convicção de que alguém com coração não poderia ter praticada tamanha atrocidade. Pero Coelho teve o coração arrancado através do peito; Já Álvares Gonçalves teve o coração retirado pelas costas.

Depois de punidos com a morte, D. Pedro revela a todos que havia se casado com Inês. Assim, os filhos do casal, caso Fernando, que tinha a saúde bastante frágil morresse, poderiam reivindicar o trono.

Oficializado o casamento, D. Pedro mandou confeccionar duas lápides no mosteiro de Alcobaça. Como assinala Garmes e Siqueira (2009), os restos mortais de Inês foram depositados na primeira; Já a segunda, esperaria a morte do rei para que ali fosse depositado seus restos mortais em frente à amada para que a eternidade tratasse de unir os dois amantes, que tiveram sua história impossibilitada diante de meros convencionalismos formais, intrigas sociais, políticas. Ainda conforme explica Garmes e Siqueira (2009), a suntuosidade dos túmulos serve também como forma de simbolizar e testemunhar a legitimidade do matrimônio entre eles.

D. Pedro mandou transladar o corpo de Inês, coroando-a rainha de Portugal. A cerimônia do translado foi cercada de uma suntuosidade poucas vezes vistas em Portugal. Durante todo o trajeto, que se segui de Coimbra (onde Inês estava sepultada) até Alcobaça, os restos mortais de Inês foram cortejados pela nobreza, pelo clero e pelo povo como uma rainha viva. A suntuosidade da cerimônia acabou passando para a memória portuguesa.

Vale acrescentar que os fatos ora apresentados tiveram como base os documentos bem como uma série de relatos históricos, contudo, é lícito afirmar que o conjunto de detalhes é bastante difícil 
de se constituir em sua integridade, o que permite afirmar que o conjunto de fatos históricos está imiscuído de uma série de fatos incertos, fruto da grande dificuldade de comprovação histórica, das falhas quanto ao arquivamento dos documentos na época, ou ainda, dos registros pouco confiáveis feitos pelos cronistas, o que torna lícito concluir que a obscuridade em torno desse fato serviu ainda mais para mitificar a história dos amantes. Assim, logo após a morte dos dois, o ideário popular tratou de acrescentar fatos e detalhes que transpuseram a realidade e acabaram entrando nos detalhes maravilhosos.

Como exemplo, Garmes e siqueria (2009) comentam que:

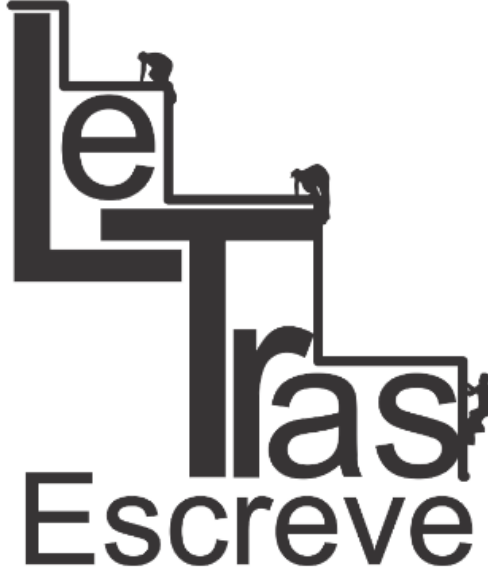

(ISSN 2238-8060)

Em Coimbra, passou-se a acreditar que Inês fora morta em sua própria casa, o famoso Paço de Santa Clara. Junto a esse palácio havia jardins, bosques e duas fontes. Em uma dessas fontes, depois chamada de Fonte das Lágrimas, existem raríssimas algas vermelhas, que a imaginação do povo relaciona com o sangue derramado da bela Inês. A outra, a Fonte dos Amores, teve seu nome dado por Camões em Os Lusíadas, em um trecho (III) dedicado a Inês de Castro (GARMES; SIQUEIRA, 2009, p18).

Além do ideário popular, também destaca-se a atuação de poetas e de grandes artistas que se aproveitaram dos fatos históricos recriando alguns e suprimindo outros. Assim, ocorreu a perpetuação do enlace amoroso entre Inês de Castro e D. Pedro, estimulando o surgimento de novas acepções bem como funções que antes não se viam em tal história.

$\mathrm{Na}$ esfera literária, os primeiros que trataram do drama de Inês de Castro foram os cronistas. Vale esclarecer que os cronistas participam tanto da literatura quanto da historiografia. Assim, o que se denomina de crônica nesse período, na verdade, trata-se de textos que versam de maneira cronológica sobre fatos importantes de reis e de nobres, bem como de uma série de fatos de suma importância desses personagens. 


\section{O caso amoroso na Literatura Portuguesa}

Conforme fortuna crítica, tem-se o registro de que uma das primeiras crônicas e, Portugal foi organizada ou redigida por D. Pedro Afonso, que era filho de D. Dinis. Sua crônica intitulada O livro do conde $D$. Pedro tem como objetivo apresentar a história do mundo. O autor inicia por Adão e Eva e chega ao período de reconquista pelos cristãos.

Contudo, foi com a crônica de Fernão Lopes que se teve registro literário pela primeira vez sobre a história de Inês de Castro. Para contextualizar a importância do escritor, pode-se citar que Fernão Lopes é apresentado pela história literária como o "pai da História" em Portugal. Justamente pelo conjunto de sua obra privilegiar uma historiografia calcada na documentação, no estilo coloquial e direto. Lopes abandona o caráter oral vigente até então no que tange à documentação de fatos. Com isso, o autor conseguiu imprimir mais veracidade aos fatos que eram apresentados. A importância do "Heródoto português" é tamanha que a sua ascensão como guarda-mor da torre do tombo, como assinala Campedelli e Barbosa (1999) é o marco inicial do Humanismo em Portugal.

Boa parte da produção de Fernão Lopes se perdeu no decorrer do tempo. Uma das poucas crônicas que foram conservadas é Crônica d'el-rei D. Pedro I, na qual se registram passagens da história de Inês de Castro.

Como aduz os críticos literários, o primeiro texto de caráter literário que versa sobre a história de Inês de Castro e D. Pedro é Trovas à morte de Inês de Castro, de Garcia de Resende. Nele, o autor dá voz à Inês de Castro, o que confere subjetividade ao poema. No texto, Inês ganha fama por amar. Dessa forma, sua morte é retratada como uma recompensa pelo fato de amar. O tom confessional de Inês reforça essa tese, uma vez que ela se coloca como inocente, como alguém que não errou e mesmo que tenha errado, esse erro fora amar o príncipe. Sua morte, ganha no texto 


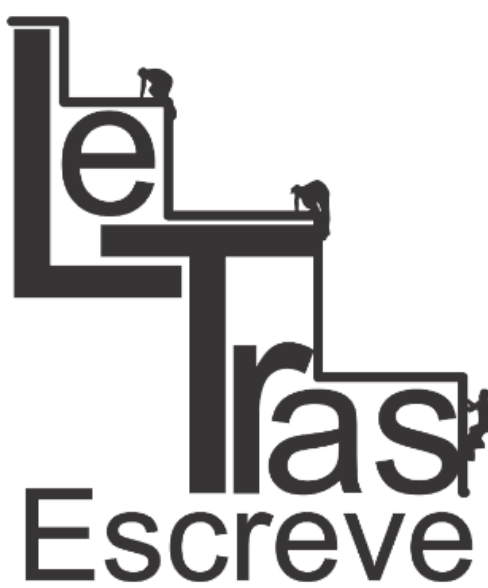

(ISSN 2238-8060) um tom bastante lírico. Parece que os reais motivos de sua morte, pouco interessaram para Garcia de Resende, que transitou num período de transição entre Humanismo e Classicismo. Como esclarece Garmes e Siqueira (2009), o autor é incluso ainda na tradição do Humanismo, mas o conjunto de obra já assinala as características de escritos ligados ao classicismo. "O Cancioneiro Geral, em que foram publicadas as Trovas, é uma coletânea da produção poética do Humanismo e, portanto, uma síntese da literatura do período" (GARMES, SIQUEIRA, 2009, p.22).

Já no período classicista, Camões, ao escrever sua epopeia, Os Lusíadas, acabou inserindo o episódio trágico de Inês de Castro no canto III de sua obra. No longo poema narrativo, Vasco da Gama atinge Melinde, cidade hoje pertencente ao Quênia, na África. O rei acaba solicitando ao almirante que conte a história de Portugal. Assim, Vasco da Gama narra os episódios históricos de Portugal nos cantos III, IV e V. Primeiro apresenta a ascensão das duas dinastias portuguesas e chega até o início da viagem. Como contextualização, é bastante oportuno citar que a apresentação da história de Inês de Castro é feita em 17 estrofes do terceiro canto. Nelas, a rainha depois de morta, tem sua apresentação explicada como vítima da inexorabilidade amorosa. Assim, Camões contribui para a transmissão do mito inesiano conferindo-Ihe uma contextualização mais lírica.

Já no Arcadismo, o modelo camoniano serviu de inspiração para a retomada da temática inesiana. Durante a vigência da estética árcade em Portugal, que vai de 1756 a 1825, retomou-se muitos aspectos clássicos, que foram ignorados pelo espírito Barroco. Dessa forma, Manuel Maria du Bocage, o poeta mais significativo do Arcadismo português, também dedicou-se a tratar do mito inesiano em suas composições. Sua composição mais significativa acerca da temática é Cantata à morte de Inês de Castro. Como se sabe, essa forma literária é dividida em duas partes: a primeira, trata-se de um longo recitativo em que se é narrado um

https://periodicos.unifap.br/index.php/letras Macapá, v. 6, n. I, Io semestre, 2016. 


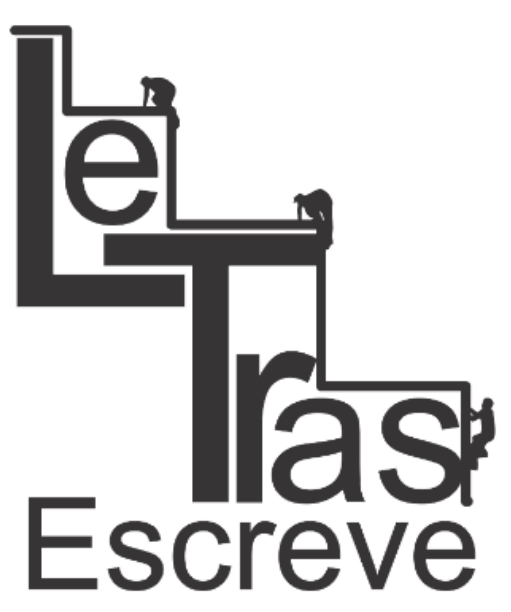

(ISSN 2238-8060)

episódio solene e uma ária, seria uma forma de poema bem mais curto e marcado pelo ritmo, o que é mais adequado para ser cantado.

Do ponto de vista temática, a crítica atribui a esse poema a tarefa de ampliar as intenções camonianas. Por essa razão, na composição de Bocage é suprimido o julgamento de Inês bem como seu apelo de defesa pela vida e pelos filhos.

Durante a história literária portuguesa, várias ênfases se revezaram no retrato do mito inesiano. Como esclarece Garmes e Siqueira (2009), predominou até o século XIX o amor desmedido, a figuração da injustiça, o ideal saudosista, a perenidade do amor, o anseio pela eternidade, a coroação depois da morte. Tais temáticas foram se revezando e alimentando a construção ideário mítico em Portugal, afinal, como já afirmado, o mito se espalhou e se constituiu numa espécie de alicerce para a construção identitária lusitana.

No final do século XIX, o mito se renovou ao passo que incorporou novos elementos em uma história que todos supunham ter se esgotado tematicamente. Enquadra-se nessa categoria as produções de Eugênio de Castro, Miguel Torga, Agustina BessaLuís e Herberto Helder.

\section{O mito inesiano em Eugênio de Castro e Miguel Torga}

Iniciaremos a análise partindo do poema de Inês e Constança, de Eugênio de Castro, poeta simbolista português, apresenta uma estrutura bastante irregular, pois é composto por dísticos e oitavas. Observamos que o próprio título do poema já anuncia algo inédito na Literatura. Até então, nunca se tinha dado voz narrativa à Constança. Agora, no poema, isso vai acontecer. O emprego do conectivo aditivo "e" deixa claro que a grande temática a ser tratada na obra é um relacionamento, ou pelo menos, uma relação entre as duas rivais: Inês de Castro e Constança. Para facilitar a análise, segmentamos o texto levando em consideração o ponto de vista da

https://periodicos.unifap.br/index.php/letras Macapá, v. 6, n. I, Io semestre, 2016. 
voz narrativa. Dessa forma, o poema pode ser segmentado em três partes:

- $1^{\circ}$ segmento: "Do meio-dia pela calma ardente até $E$ num sôfrego beijo ficam presas";

- $2^{\circ}$ segmento: "Ai, minha linda Inês até Fazer agora o mesmo, se não fosse";

- $3^{\circ}$ segmento: "Ai, quem me dera até $E$ em seus lábios desfiou-se".

No $1^{\circ}$ segmento do poema, a voz que narra os fatos não é a de Constança, nem de Inês, mas sim de alguém que conhece intimamente as duas personagens. Carregado de uma linguagem extremamente poética, permeada por comparações e por sinestesias, a voz narrativa do poema inicia retratando o Rio Mondego em um dia de "calma ardente". Essa calma é tão intensificada devido o zunido das cigarras que aparece todo seco.

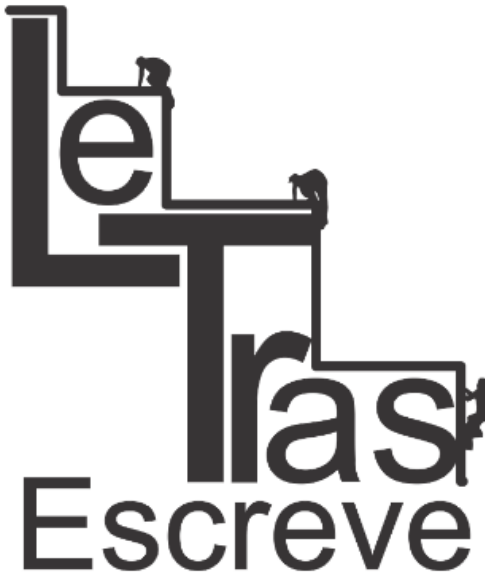

(ISSN 2238-8060) Essa situação de calmaria da natureza é comprovada ainda por meio do emprego de uma símile: a comparação da natureza com uma farta jiboia. O traço comum entre elas é que ambas descansam pesadamente.

Após essa introdução, aparece um indício, uma sugestão de um relacionamento entre Inês e Constança, uma vez que as duas estão dormindo juntas. Essa sugestão, pode-se falar, é comprovada em outro trecho do segmento analisado bem como no segundo segmento, mas aqui no $1^{\circ}$ segmento, ela ganha esse tom sugestivo basicamente devido ao emprego da adjetivação um tanto quanto inusual em língua portuguesa. A hipálage no trecho "fresca tenda" "tenros salgueirihos" colabora para essa sugestão.

O relacionamento entre as duas ainda é figurativizado como uma relação de pecado, de sensualidade. Constança é esbelta e morena tal qual a pérola; Já Inês é esbelta, é rósea e loura como um pessegueiro. Constança é uma ave, Inês é um fruto. Dessa descrição das duas, chegamos à conclusão de que Inês simboliza o modelo de mulher ideal, pois é loira e rósea. Constança é morena, por isso não é idealizada. Ao empregar ainda a aproximação de Inês 


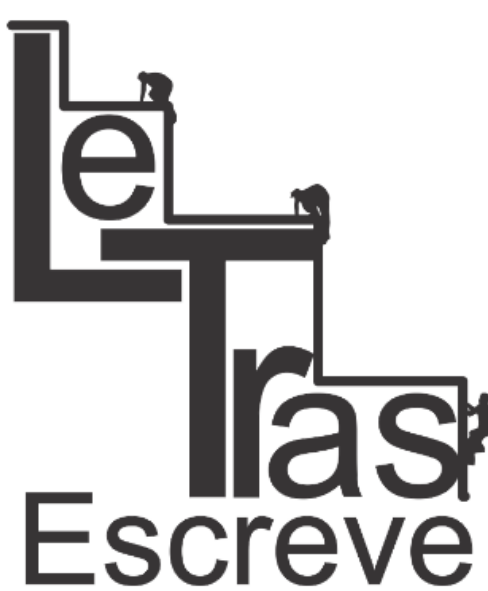

(ISSN 2238-8060) a um fruto, há a sugestão de uma relação de pecado. Relação essa comprovada pelo fato das duas "amigas" estarem dormindo com os dedos entrelaçados tal qual ocorre num relacionamento entre marido e mulher. As duas ainda julgam terem se beijado.

O segundo segmento do texto, ora dividido sob a ótica da voz narrativa, surge a partir do trecho "Ai minha linda Inês". A partir desse momento, abre-se espaço para Constança. O eu-lírico vale-se de um tom nostálgico, rememorando fatos da infância. Ela conclama, convida Inês a reviver esse passado permeado pela simplicidade, pela contemplação à natureza. Nesse sentido, a expressão de chamamento que abre esse segmento é uma Figura de Linguagem denominada de Apóstrofe. Constança revive esse passado num tom saudosista ao mesmo tempo que lamenta não poder continuar mantendo o relacionamento. O emprego da Oração com valor condicional carregado com reticências permite ao leitor concluir que a relação entre as duas não pode ser como dantes devido à existência de Pedro.

É lícito afirmar que Constança atribui a ele a culpa pela impossibilidade desse relacionamento. Esse raciocínio de Constança é impedido devido ao fato de Inês forjar a conjunção carnal. Fica evidente que é Inês é quem inicia devido a sua caracterização como sendo o fruto, figura que nos leva ao já mencionado tema do pecado. A caracterização dela ainda é de ser travessa. Inês age como uma serpente, que domina e encanta sua vítima, daí a caracterização de Constança como fraca. Como Constança não consegue livrar-se desse encanto, a única saída é ceder e se entregar também. Esse fato serve de justificativa para a consumação do relacionamento sugerido no $1^{\circ}$ segmento. Relação, aliás, passível de ser descoberta, pois as duas ficam com bastante medo sempre que algo ou algum barulho ocorre.

No terceiro segmento do texto, por fim, mais uma vez, tem-se a voz narrativa de Constança, que observa o corpo nu de Inês e deixa evidente uma admiração pela cortesã. Ela se coloca numa

https://periodicos.unifap.br/index.php/letras Macapá, v. 6, n. I, Io semestre, 2016. 


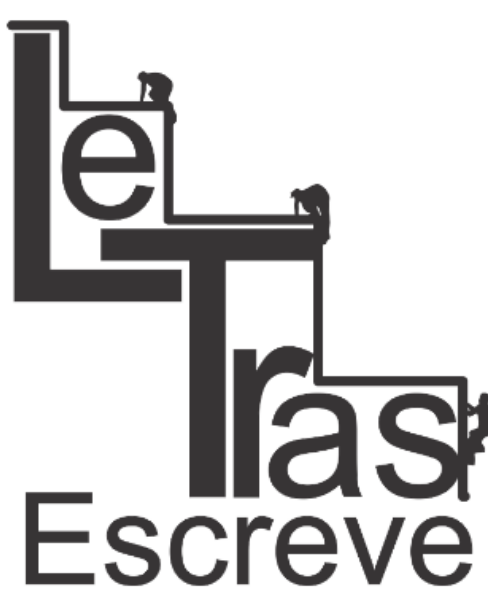

(ISSN 2238-8060) posição de inferioridade porque queria ser igual a Inês (da cor do pecado) para que Pedro a amasse.

Fica explícito, então, no poema analisado que Eugênio de Castro inova ao abordar a temática inesiana por dois motivos: sugere uma relação lésbica entre as duas. É inovador também porque dá voz narrativa à Constança, fato que não ocorreu em nenhum outro poema, pois, até então, os textos que travavam diálogo com o mito de Inês de Castro abordavam as consequências trágicas de um amor proibido.

Agora, passemos à análise do poema Inês de Castro, de Miguel Torga. O autor em questão é natural de São Martinho de Anta. Com mais de 50 obras publicadas, destaca-se por ser contista, romancista, ensaísta e dramaturgo. Torga traz em sua história experiências como vida rural, emigração, enfim uma vida sofrida, onde presenciou morte e a miséria. Experiências essas que se refletem em suas obras.

A sua obra, recheada de simbologia bíblica, encontra-se, antes, imersa num sentido divino que transfigura a natureza e dignifica o homem no seu desafio ou no seu desprezo face ao divino. A ligação à terra, à região natal, a Portugal, à própria Península Ibérica e às suas gentes, é outra constante dos textos do autor.

Nos primeiros versos do poema de Torga, notamos a referência à gravura que está no túmulo de Pedro, seu grande amor, que diz "Até o fim do mundo", pois o poema se inicia com o seguinte verso "antes do fim do mundo despertar", mas aqui também notamos uma característica do autor, esse que é grande admirador dos feitos humanos, ou seja, do Homem. Para Torga, a divindade só é grande porque assiste como expectador a luta do homem para sobreviver, criar, entre outros. Assim, Torga entende que Deus só é divino, porque não passa pelo que os homens passam, por essa razão, o poeta exalta o homem. O poema como próprio nome deixa claro, descreve a história de Pedro e Inês.

https://periodicos.unifap.br/index.php/letras Macapá, v. 6, n. I, Io semestre, 2016. 


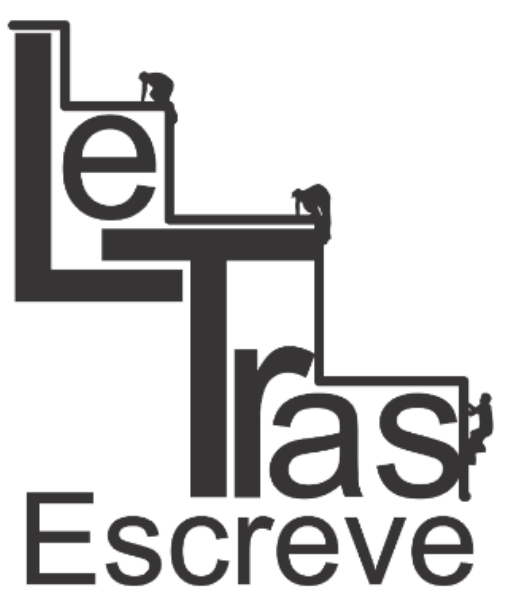

(ISSN 2238-8060)

$\mathrm{Na}$ segunda estrofe, isso se evidencia ainda mais, pois fala do Amor de Pedro e Inês em que muitos se levantaram contra, amor esse que superou a morte, como diz na segunda estrofe " $E$ mostrarIhes que o amor contrariado/Triunfa até a própria sepultura", aqui pode-se dizer que faz referência à história de Jesus Cristo, que ressuscitou, assim como o amor de Inês e Pedro, além de que as gravuras no túmulo de Inês é sobre a vida de Jesus Cristo. E mais uma vez nos versos, "O amante, mais terno e apaixonado/Ergue a noiva caída a sua altura", referindo ao episódio da morte de Inês, pois Pedro mesmo com a morte de sua amada, ainda permanece fiel a ela, e a coroa como rainha. E ainda manda construir os túmulos frente a frente, para que no dia do juízo final, ao se levantarem da morte, que a primeira pessoa a ser vista pelos dois fossem um ao outro.

$\mathrm{Na}$ terceira e última estrofe, o poeta quando diz Ao mito do poeta, a linda Inês... faz referência aos versos dos Lusíadas, em que o autor, a se referir a Inês, sempre se refere a ela como "Linda Inês". É na mesma estrofe que o autor estabelece uma relação de intertextualidade com o clássico Romeu e Julieta da literatura inglesa, em que o único erro dos dois foi terem se apaixonado, pois eram de famílias rivais. Já no caso do poema de Torga, mostra a rivalidade dos países quando diz "A eterna Julieta castelhana/Do Romeu português". Além disso, quando nos referimos à língua castelhano, nos referimos a uma língua chula, vulgar, do povo, pois a língua dos intelectuais, da alta sociedade era a língua espanhola.

\section{Considerações Finais}

Procuramos enfocar a importância do mito de Inês de Castro e D. Pedro na literatura portuguesa. Considerando a concepção de mito, que há no texto intitulado Mito e Realidade de Mircea Eliade, em que o mito é visto como algo vivo, uma realidade capaz de ser reproduzido ainda hoje para realizar os mesmos feitos dos seres 


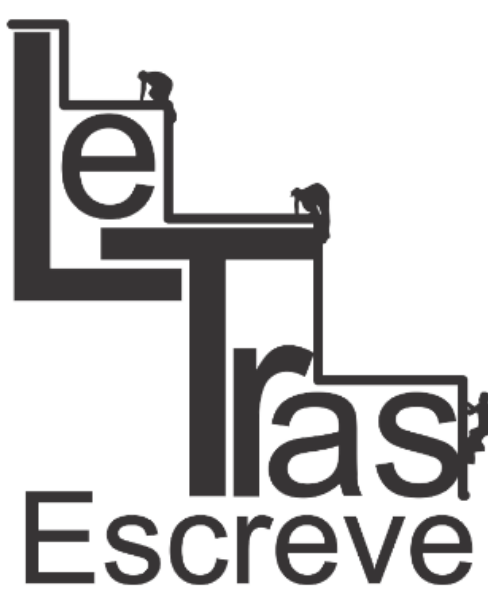

(ISSN 2238-8060)

mitológicos, assim sendo algo sagrado. Segundo Mircea, o mito seria uma história sagrada que tem a finalidade de relatar um acontecimento ocorrido no tempo primordial. Dessa forma, a função que é conferida a o mito é descrever as várias irrupções dramáticas do sagrado ou do sobrenatural no mundo, definição essa que vão ao encontro do mito de Inês, que se tornou uma historia sagrada que ultrapassa o tempo e até mesmo a morte, assim como a história de Inês: linda, trágica e sofrida.

Ao longo da história literária portuguesa, vários autores trataram da temática inesiana, o que serviu para alicerçar as questões referentes à identidade em Portugal. $\mathrm{Na}$ atualidade, o universo temático inesiano, compreende uma vasta produção de textos que se valeram de diferentes formas para retratar essa relação amorosa. Assim, a temática da universalidade, da vingança, da fugacidade, do ódio, do impedimento amoroso são alguns exemplos de como essa relação perpassa a história literária portuguesa, incluindo nesse rol até exemplos mais audaciosos como se percebe na produção de Eugênio de Castro, que sugeriu uma relação lésbica entre Inês e Constança.

\section{Referências bibliográficas}

CAMPEDELLI, S.Y; SOUZA, J.B. Produção de textos e usos da linguagem. São Paulo: Saraiva, 1999. 288p.

CASTRO, E. in. ANDRADE, E. Antologia Pessoal da Poesia Portuguesa. Campo das Letras. Porto. 1999.

ELIADE, M. Mito e realidade. 3 ed. São Paulo: Perspectiva, 1991.

GARMES, H; SIQUEIRA, J.C. Cultura e Memória na Literatura Portuguesa. Curitiba: IESDE Brasil S.A., 2009.

TORGA, M. Inês de Castro. Disponível em < http://inescastro1000.blogspot.com.br/2010/03/poema-de-migueltorga.html>Acesso em 17/10/2015.

Recebido em 28/01/2016. Aprovado em 12/03/2016.

https://periodicos.unifap.br/index.php/letras

Macapá, v. 6, n. I, Io semestre, 2016. 